\title{
PDGFC Gene
}

National Cancer Institute

\section{Source}

National Cancer Institute. PDGFC Gene. NCI Thesaurus. Code C104749.

This gene plays a role in growth factor signaling. 